\section{Catherine Cooke}

Author's address

Department of Design and Innovation

Faculty of Technology

The Open University

Walton Hall

Milton Keynes

MK7 6AA

UK

\title{
What is the point of saving old buildings?
}

\author{
This paper was written for a special issue of the Ekaterinburg \\ Architecton devoted to the rich Constructivist heritage of that hitherto \\ closed city beyond the Urals. Docomomo-Russia has an active \\ working party there', but the combination of public poverty and \\ vigorous real-estate pressures is making the fate of these buildings \\ uncertain. This paper sought to offer some fundamental structuring \\ ideas to the debate. We publish it here to stimulate discussion of \\ problems also current elsewhere, but the author stresses that it \\ should be read with its original purpose and audience in mind.
}

What is the real purpose for which we are conserving buildings and recording them in documentation? This question is so fundamental that one would suppose it had been answered. At least one would assume that it had been clearly answered in the wider field of 'heritage' and conservation to which our Modern Movement activity is a young and still peripheral addition. But not so. One may scour the accounts of twentieth-century debates about building conservation in vain to find any engagement with these larger, deeper issues. ${ }^{2}$

In the English-language literature at least, the wave of recent thinking that one may broadly call 'postmodern' has produced far-reaching and influential explorations of the multiple ways in which societies of the past and today have used history for the purposes of their present. ${ }^{3}$ But whether through lack of literacy among those concerned with buildings, or whether through the pragmatic desire to avoid deeper-level conflicts that could fatally impede the saving of actual fabric, these fundamentals seem to have been suppressed in the debates around architecture. In the early-modern period of the nineteenth century, however, when the frameworks and even organizations within which we still operate today were formed, the deeper questions of 'why?' were not hidden behind the pragmatics and realpolitik. They were still in the foreground of action.

Suppression of this debate has left us now in a panic to save everything. This produces a kind of heritage constipation which totally immobilizes us. On the surface, this constant panic seems to be a feature of the private ownership culture which prevents a larger 'planning' of our national architectural stock. But the distinction between 'private' and 'planned' is not so simple. All countries attempt to make some planned prioritization of their stock by their bureaucratic procedures of monument designation - in Britain we call it 'listing'. But this too operates by panic. Because the listing has no direct connection to availability of money, and no-one knows which objects may attract the money for restoration in future, every possibly valuable building of every type must be listed, just in case it turns out to be the only example that can ultimately, and in some form, be 'saved'. There is no higher-level intellectual framework for a collective selectivity which could liberate us from this impasse. It is time, perhaps, to go back to some of those people who did ask 'why?' in order to regain the confidence with which to move forward more freely

\section{The UK Modern Movement stock}

My own research has always focused on Soviet Modernism. So when colleagues proposed that I chair Docomomo-UK I had to educate myself more systematically about our stock of relevant buildings here. I started assembling the various lists and preliminary 'registers' that the UK Momo specialists have made in recent years. And I was frankly depressed. I hoped for great revelations but the impressions I had formed in ignorance were sadly confirmed.

The first reason for my depression was that this building stock is only in a technical sense 'British'. Virtually all Momo buildings of any real merit in the 
UK were done by foreign architects: from the USA and Canada, from our East African colonies, from Russia, from Germany and Eastern Europe. Some of them passed through. Others stayed. But very little of what they built in the country was generated by any indigenous cultural factors. Nor was it used or even seen by the population at large.

With the change in national mood after the Second World War the architectural situation also changed. Through widespread publicity, Modern architecture and town planning became part of a 'new Britain' deeply desired by much broader sections of the population and promised them by a new Labour government. But in the high period of Modernism before the War this architectural philosophy was always marginal in Britain.

This leads to the second feature which struck me about our UK Momo stock: the limited range of types which these very peripheral, mistrusted foreigners built and the élite social character of the majority of their clients. The facts here show clearly why this architecture was so unconnected to the rest of UK culture. UK Modernism consisted overwhelmingly of private houses on secluded sites in the richer areas of south-east England around London [Figs. 1a and b]. The clients were rich and slightly 'cosmopolitan' people from fashionable circles of professional, intellectual and commercial life: people, that is, who were very like the architects themselves.

There is no single UK town, far less a city, where modern architecture before the Second World War was part of any larger programme. The only partial exception was perhaps Leeds, where a complex similar to Vienna's Karl-Marx-Hof had some success but was destroyed in the 1970s. There were only two small-scale attempts at whole settlements. Both were for commercial companies and located on the northeast edge of London, in Essex. One was a demonstration project by the main manufacturers of Modernist steel windows, Crittalls; the other was for the employees of the Czech shoe company Bata.

The individual UK Momo buildings of that period which reflect any social innovation can be counted on one hand. The most important in its social welfare implications was the Finsbury Health Centre [Fig. 2a] by Russian emigré Berthold Lubetkin, completed just before the War. Of similar date and architecturally the most modest was the 'village

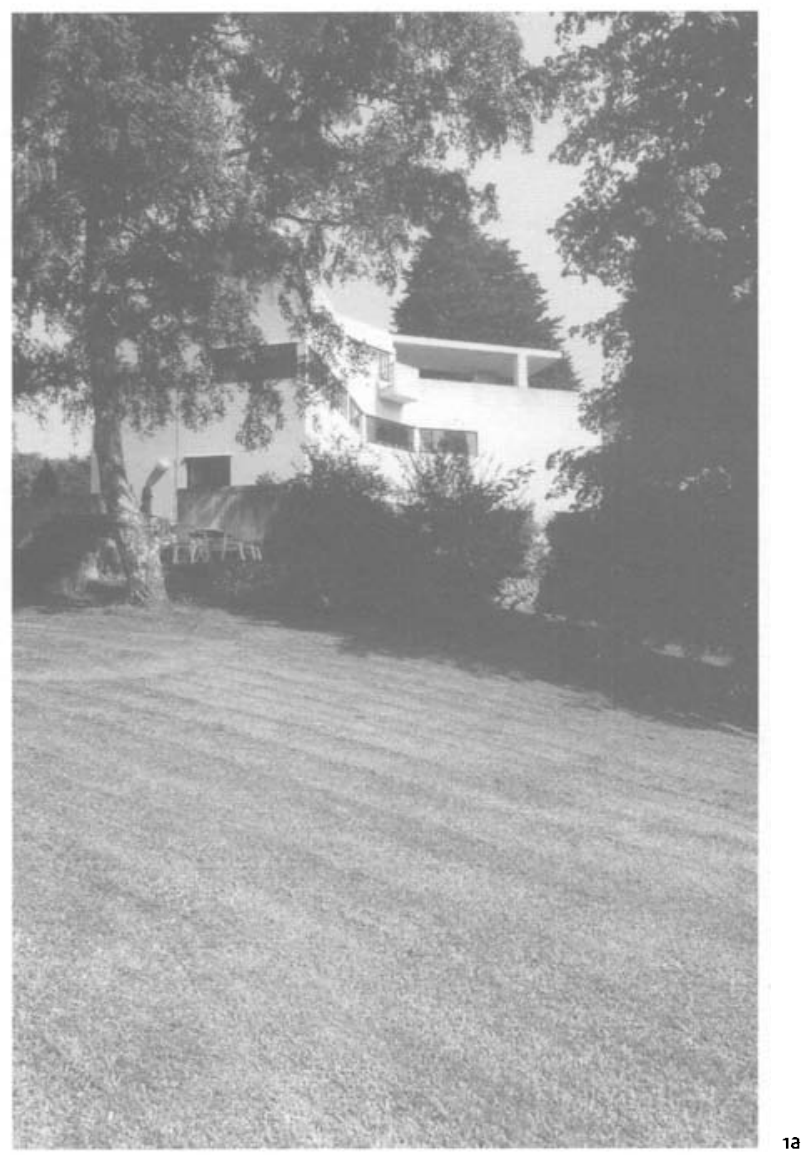

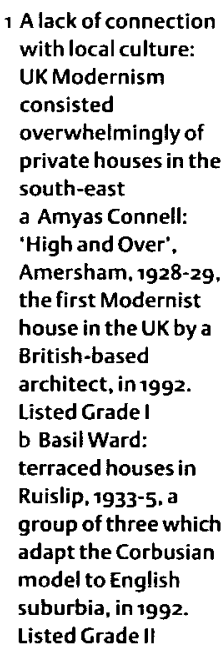

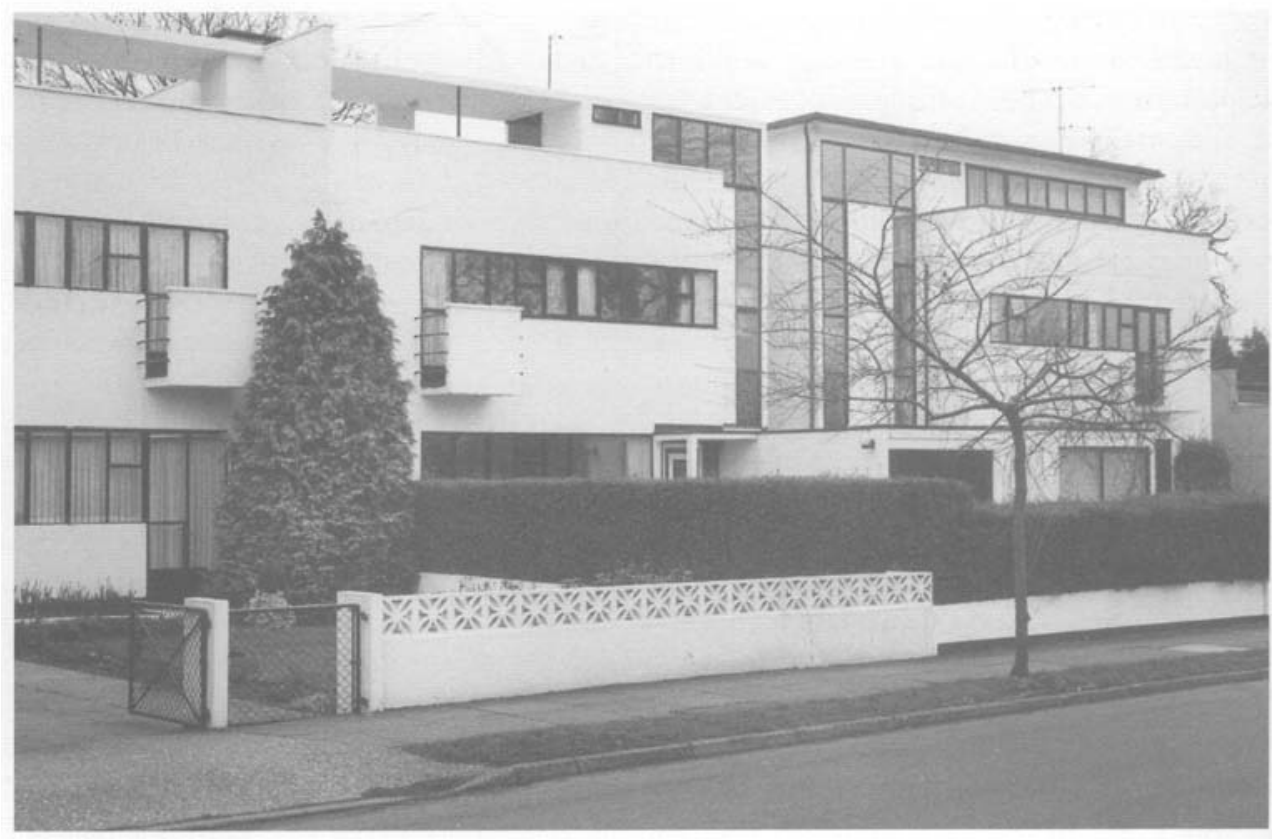


college', a progressive concept in rural education pioneered in Cambridgeshire, on which Walter Gropius collaborated with the English architect Maxwell Fry. More self-consciously Momo was the so-called Isokon (or 'Lawn Road') apartment block [Fig. 2b] by the Japanese-educated Canadian, Wells Coates, which attempted to combine Existenzminimum units into a middle-class English version of Moisei Ginzburg's dom Narkomfin in Moscow [Fig. 2c]. The client in London was a progressive furniture manufacturer and the occupants were mainly famous intellectuals, including both Gropius and Moholy-Nagy. Social welfare was again given dramatic architectural form on the cliff-top at Sully near Cardiff [Fig. 2d], where the young architect Dennis Harper gave the South Wales coal miners some of the UK Modernism's most magnificently glazed spaces as environmental medicine for their tuberculosis.

\section{British poverty and Russian riches}

Architecturally the finest of these socially 'progressive' UK buildings was the cultural centre which stands on the English Channel coast in the small bourgeois town of Bexhill. This was a kind of freak. The town had an aristocratic mayor with a socialist vision, Earl de la Warr, who launched the competition which was won, against much public and professional outcry, by Erich Mendelsohn from Germany and Serge Chermayeff from Russia. This socalled De La Warr Pavilion [Fig. 2e] is arguably our most important pre-war Momo building. It is listed Grade I as a monument. One of our best-known Momo conservation architects has been appointed for the task of restoring it as a much-needed cultural centre for the town. ${ }^{4}$ After years of struggle by local people [Fig. 2f], half the job is done. But even the UK official National Lottery, which has offered hundreds of millions of pounds to cultural ventures over recent years, has preferred to create new 'visitor attractions' full of 'virtual experiences', which are now in crisis because the public does not visit them, rather than see this wonderful seaside theatre and cultural centre fully revived as a social and architectural showpiece.

What else do we have? Among the numerous private houses some are elegant, but few are architecture of world class. The majority of Modern Movement public housing and community buildings in Britain are workmanlike schemes built by local council architects for our postwar Labour government.

It was the relative poverty of this UK Momo legacy in comparison to many countries of Europe, but in particular, in relation to the riches I am accustomed to study in Russia, that posed in my mind so urgently the question of why do we try to save any of this? And why, by extension, do we save any buildings at all? The Constructivist heritage of Architecton's home city of Ekaterinburg is opposite in every respect. Its designers were native Russians. It was erected specifically for the use of ordinary working people, and more than that, as the embodiment of a state programme for changing their lives in socially progressive ways. That was of course the central factor distinguishing all Soviet Constructivism, Rationalism and other Modernist work from its European Momo contemporaries. There were no private clients, only different client organizations who are parts of that programme. The range of individual building types and whole complexes reflects the integrated vision of a whole city: 'new Sverdlovsk' (as the city was called in Soviet times), with a unique role to play in national development. At least one good example of every new building type of the early Soviet period still stands either in the city-centre or in the new little 'socialist town', the sotsgorod of Uralmash to the north. Together they are unique as a living museum of the novyibyt', 'the new socialist way of life' of early Soviet years and of its social support systems [Figs. 3a-f].

The UK has recently been awash with money but even our finest works are too 'foreign' to the national identity to attract funds. In Ekaterinburg the buildings are central to the city's identity but there is equally no money. Thus the problems differ in every dimension but the need for principles to guide priorities is equally clear. In both cases each element of the stock needs to be evaluated through a genuine debate about its potential cultural role, not just in the functional sense, but in the public and private psychology.

\section{Should buildings die or be allowed to kill people?} All over the world our approach to the Momo heritage has been complicated by the fact, so often discussed in Docomomo forums, that much of this architecture was programmatically intended to be short-life and expendable. Its very 'functionalism' implied that social or technical progress might cause it to be replaced without romance or nostalgia just as we would replace a car or a camera (Heynen, 1991).

In the close focus of Docomomo debates, especially when the Docomomo mission was new and under threat, those arguments about original intentions seemed to make our buildings a 'special case'. I well recall the sense of outrage when two speakers at the first Docomomo International Conference in Eindhoven in 1990 advanced the argument that this short-life philosophy of the original designers invalidated the whole basis of the new campaign (Reinink, 1991). It was seen as disloyalty. We did not need people to undermine the project just as it was being born. People spoke of 'fifth columnists in our midst'. The London journalist Martin Pawley made the case very lucidly (1991) and his ideas are worth returning to today, as I shall below. Now we can listen to that viewpoint more calmly, however, for Docomomo has achieved recognition for these buildings in UNESCO and across the world.

This parity of status with earlier architectures reminds us that the notion of buildings having a limited functional or physical life is not in fact unique to the Modern Movement. In our century the social and technical time-scales have been shortened but the principle is not novel. Throughout history those buildings which were not explicitly erected as memorials to some 'eternal' religious or civic values were assumed to grow, adapt, die and be replaced by 

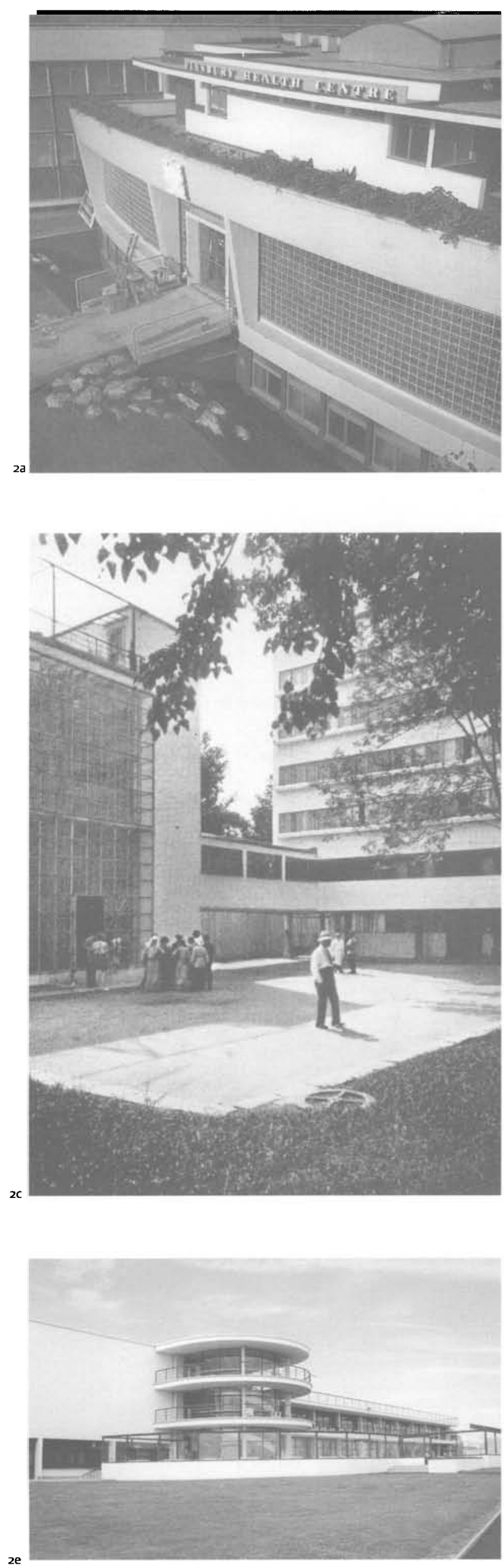

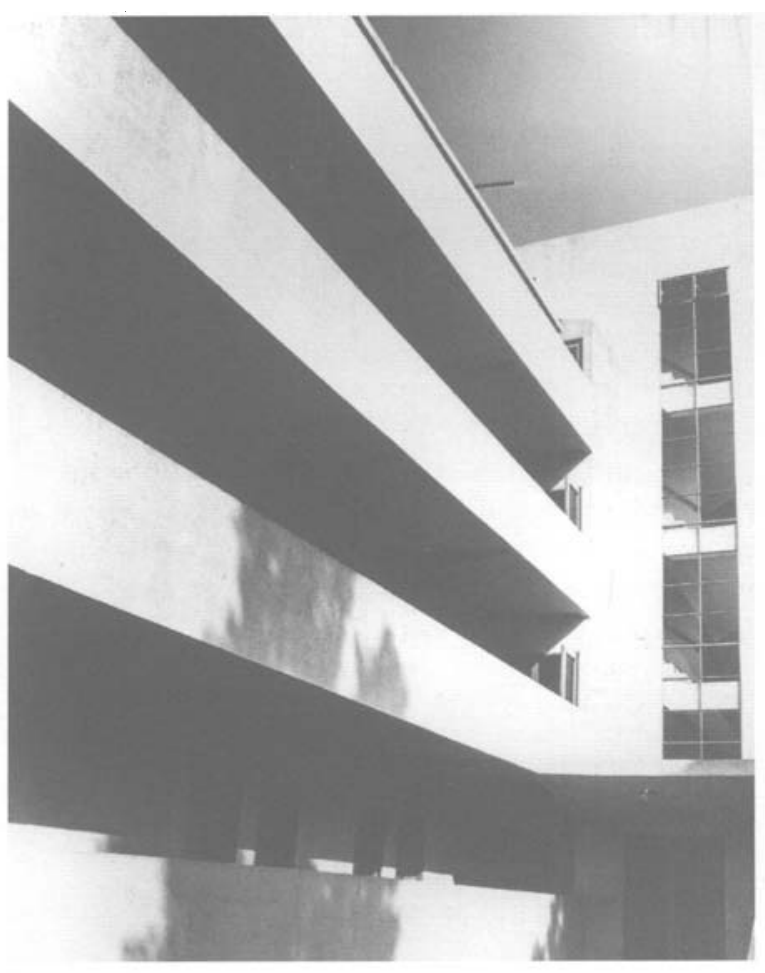

$2 b$

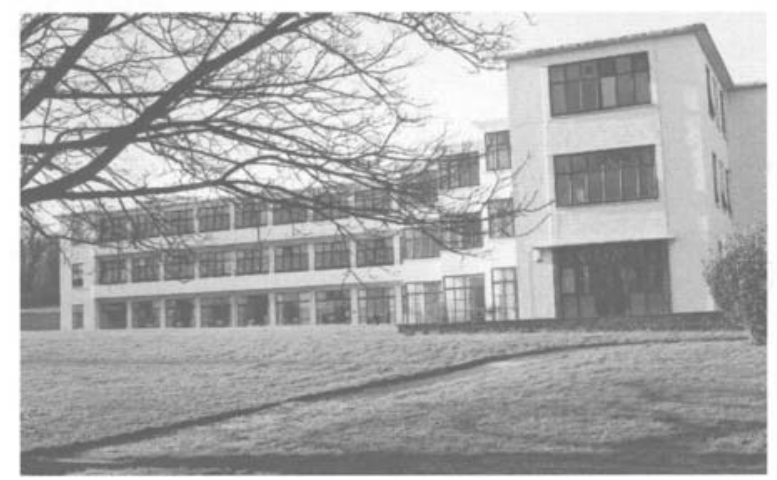

\begin{tabular}{|c|c|c|}
\hline $\begin{array}{l}4 \text { Rare examples of } \\
\text { social innovation in } \\
\text { pre-war UK buildings } \\
\text { a Berthold Lubetkin } \\
\text { and Tecton: Finsbury } \\
\text { Health Centre, } \\
\text { London, } 1937 \text {. } \\
\text { Entrance front. Listed } \\
\text { Grade II } \\
\text { b Wells Coates: Isokon } \\
\text { flats, Lawn Road, } \\
\text { London, 1933-34. } \\
\text { Entrance stair and } \\
\text { access galleries. Listed } \\
\text { Grade I } \\
\text { c The inspiration for } \\
\text { the isokon flats. Moisei }\end{array}$ & $\begin{array}{l}\text { Ginzburg, Ignati } \\
\text { Milinis and S. L. } \\
\text { Prokhorov (engineer): } \\
\text { semi-collective } \\
\text { housing complex for } \\
\text { employees of the } \\
\text { Finance } \\
\text { Commissariat, } \\
\text { Narkomfin, Moscow, } \\
\text { 1928-30. Photograph } \\
\text { soon after completion } \\
\text { d Dennis Harper, in } \\
\text { the office of Pite, Son } \\
\text { \& Fairweather: } \\
\text { tuberculosis hospital } \\
\text { for coal miners, Sully, } \\
\text { South Wales, 1931-38. }\end{array}$ & $\begin{array}{l}\text { Seaward elevation } \\
\text { in } 2000 \text {. Listed } \\
\text { Grade II } \\
\text { e Erich Mendelsohn } \\
\text { and Serge } \\
\text { Chermayeff: De La } \\
\text { Warr Pavilion, } \\
\text { Bexhill-on-Sea, } 1935 \text {. } \\
\text { Seaward front. } 1997 \text {. } \\
\text { after restoration by } \\
\text { John McAslan \& } \\
\text { Partners. Listed } \\
\text { Grade I } \\
\text { f Newsletter-head of } \\
\text { the Pavilion Trust. } \\
\text { Bexhill-on-Sea, } \\
\text { March 1998 }\end{array}$ \\
\hline
\end{tabular}

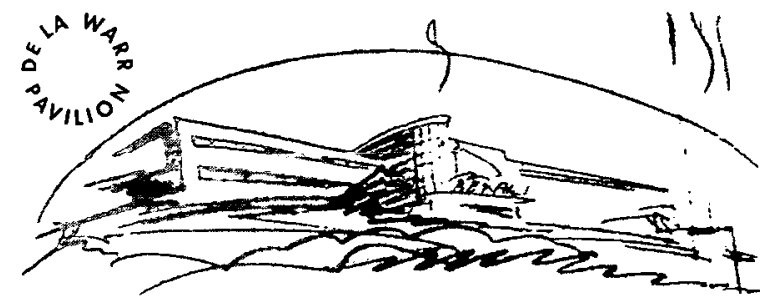

Pavilion Trust Newsletter March 1998

Ambitious plans await Lottery bid 


\begin{tabular}{|c|c|}
\hline $\begin{array}{l}\text { Ekaterinburg } \\
\text { (formerly Sverdlovsk): } \\
\text { examples of new } \\
\text { building types of the } \\
\text { early Soviet period } \\
\text { a Moisei Cinzburg. } \\
\text { Alexander Pasternak } \\
\text { and S. L. Prokhorov } \\
\text { (engineer): } \\
\text { integrated semi- } \\
\text { collective housing } \\
\text { complex for workers } \\
\text { of the Urals Economic } \\
\text { Administration, } \\
\text { Ekaterinburg. } \\
1930-33 \text {. After partial } \\
\text { facade restoration, } \\
198^{2} \\
\text { b Sergei Zakharov: } \\
\text { workers' law centre, } \\
\text { Ekaterinburg. 1930. } \\
\text { in } 1998\end{array}$ & $\begin{array}{l}\text { c Kasian Solomonov: } \\
\text { central post and } \\
\text { telegraph office, } \\
\text { Ekaterinburg. 1931, } \\
\text { in } 1998 \\
\text { d Peter Oransky: } \\
\text { industrial training } \\
\text { college for workers } \\
\text { of Uralmash, } \\
\text { Ekaterinburg. 1931. } \\
\text { in 1998 } \\
\text { e Peter Oransky: } \\
\text { workers' housing } \\
\text { district, Uralmash, } \\
\text { Ekaterinburg, } \\
\text { 1931-33, in 1998 } \\
\text { f Georgi Golubev: } \\
\text { Urals Worker } \\
\text { newspaper offices } \\
\text { and printing house, } \\
\text { Ekaterinburg. } \\
\text { 1929-30. in } 1998\end{array}$ \\
\hline
\end{tabular}
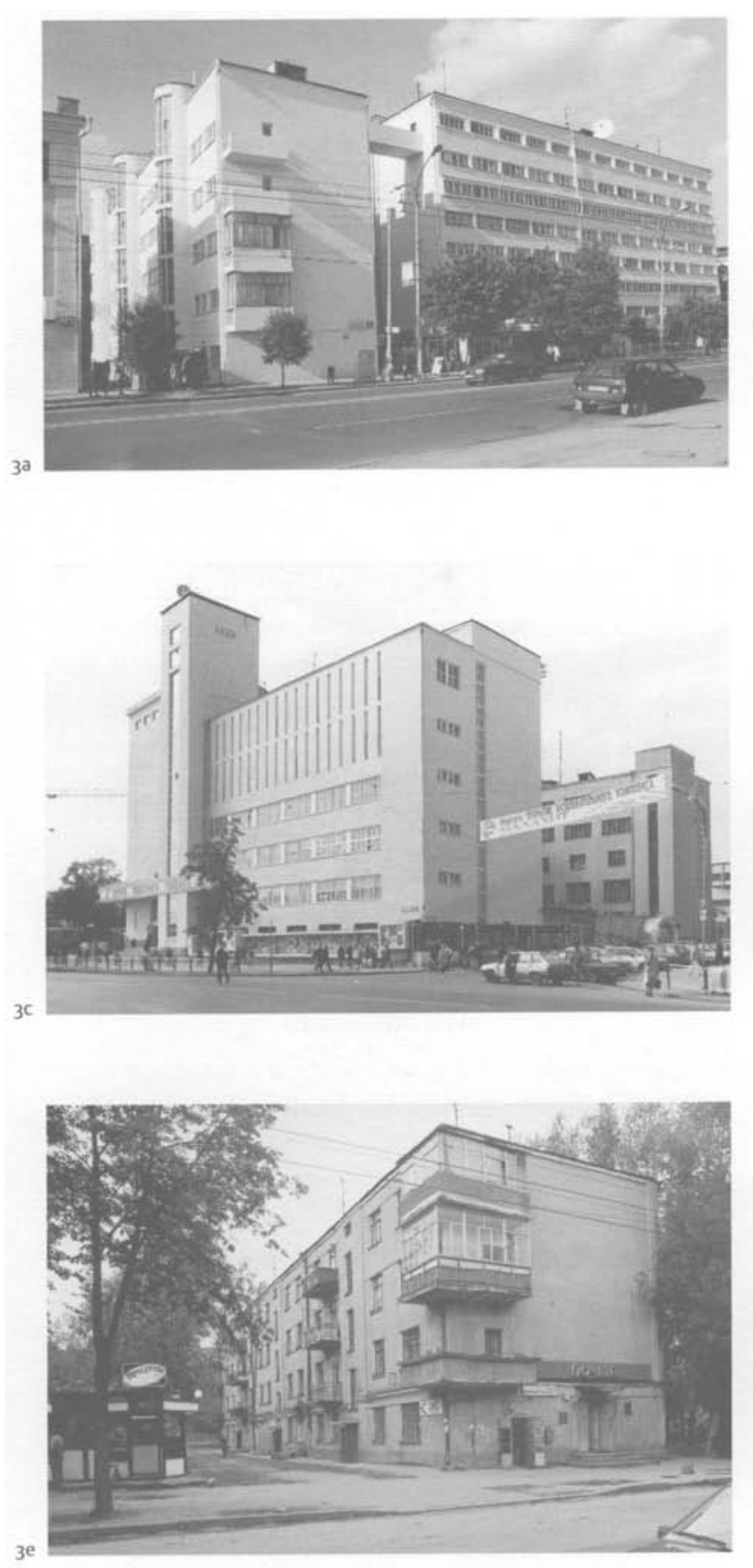
'fire-fighting', that is, 'responding to an emergency'.
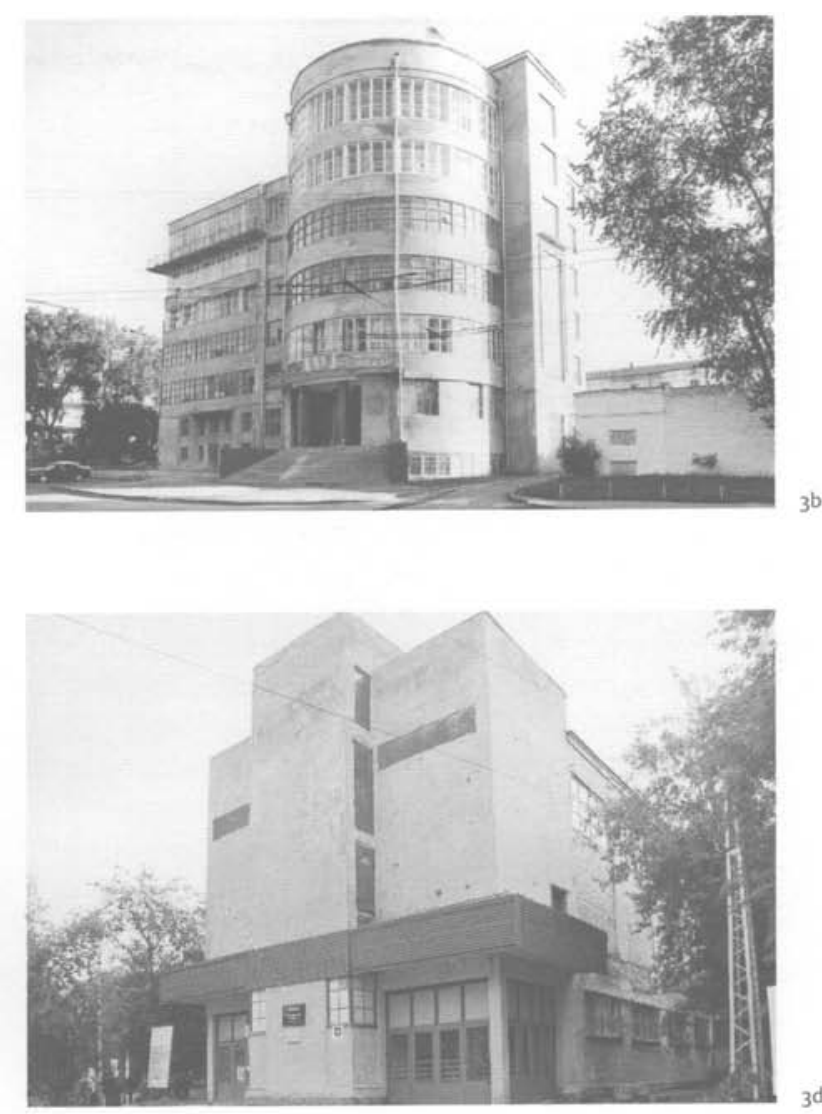

the next generation of their species like all other objects in the natural world. The very 'respectability' of Momo buildings now helps us to see them in this larger historical timescale and to recognize the similarities with other periods as well as the differences. This focuses us again on the question of 'why save?'

At the scale of the individual building, whatever its age, the conservationists usually find themselves We all know these situations so well. But the firefighter knows why he leaps to every fire: human life may be at risk and that danger must not be allowed to spread. For the firemen in our societies, the saving of property, even of 'heritage property', is a secondary priority to the saving of every human life. But one can imagine societies with a different morality, where the supreme cultural product might be deemed more important than a few lives.

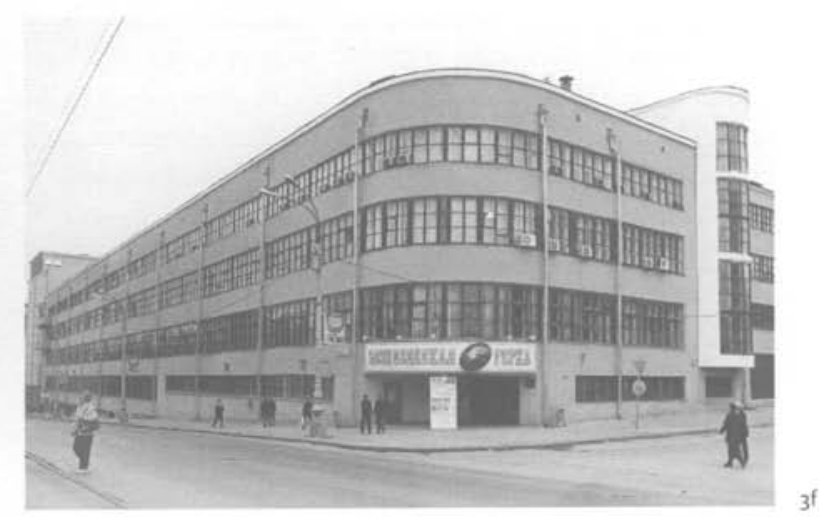

What is the point of saving old buildings? | Catherine Cooke 
$142|\operatorname{arq} \cdot \operatorname{vol} 4 \cdot \operatorname{no} 2 \cdot 2000|$ issues

This sounds far-fetched, but in fact the listing system, as it operates for example in the UK, has an effect which is ultimately very similar to that, in the way it regards individual owners' lives as 'expendable' in relation to saving a listed monument. Government agencies list buildings according to a mass of criteria which are defined in terms of what 'significance' they have and what they 'illustrate'. For twentieth-century buildings, they are seen as having significance, in the words of the relevant legislation, 'as key exemplars for each of a range of building types' (Department of the Environment, 1994). But listing of a building as 'an architectural monument', even at the highest level of quality and importance (Grade I) is not (except to a very marginal extent) a statement of actual collective support for the building. It may be deemed 'significant' but no commensurate finance follows from its listing. On the contrary. Listing of their building can destroy ordinary owners financially and has been known to drive those who inherit grand houses to suicide. The entire energy and resources of people and organizations have to be diverted from any other useful activity in order to preserve their building to some arbitrary standard. This is where private ownership of property and public determination of value are fatally at odds. The municipality of Bexhill which owns the De La Warr Pavilion is only one example, unable to care for this national monument from its own resources and refused help from above. They are stuck. Innumerable owners of quite minor buildings find themselves in this position because listing automatically includes 'most buildings up to 1840 which survive in anything like their original condition' (Delafons, 1997).

The experimental nature of twentieth-century buildings creates particularly dire situations. Many major educational institutions, for example, have purpose-made modern buildings riddled with structural faults and functional shortcomings which bureaucrats have decided to list. My own Cambridge college is one. Instead of being able to make sensible modifications they must somehow find millions of pounds that would be far better spent, if they can be raised at all, on real facilities for modern education. Local councils, lacking real knowledge and fearful of criticism, make conditions which prevent any viable outcome being found, in order to protect themselves. What kind of collective assertion of cultural values is that? Many people who are notionally 'rich' in the property they own and absolutely not Socialist in their politics would say that outright nationalization is ultimately better than this situation. It might enable the state to seize their property, but at least it would allow them to get on with their own lives. In this situation the heritage becomes more hated than loved among those who should be its champions.

\section{Docomomo rationales}

If we look into the basis of this power to list, exercised apparently for the collective cultural good, it has no explicit philosophical or moral basis. As one recent writer has dared to say of our fundamental UK listing legislation, passed in 1947:

'No advice was given to local planning authorities about the purpose of listing ... Presumably it was assumed to be self-evident that a nation should safeguard its heritage of fine buildings, as it did its collections of paintings and sculpture'

(Delafons, 1997).

One important source of confusion is revealed in this comment. While architecture may on one level be an art, its products have complex functionalities and represent major investments. These are not simply expressive images like paintings and sculpture. Yet even the discussions of Docomomo have not taken us beyond this confusion. We still find it in the writing of Professor Hubert-Jan Henket, famous practising architect as well as founder and chairman of the whole Docomomo movement, in the movement's fundamental book published last year.

'The first question is why do we want to keep objects of the past if they are not functionally and economically useful? As [I have] mentioned, it is primarily our appreciation for the work of art, our love and fascination for its beauty, its mystique and its presence.'

To that he adds a second, essentially professional, purpose.

'There are also more scientific reasons for doing so, such as assembling knowledge and understanding the way of life of our predecessors, their technical innovations, the physical performance of their buildings, etc. Everything we do, imagine, make or invent, has its roots in the past. So proper knowledge and understanding of our recent past is a key to development in the future' (Henket, 1998). Both the aesthetic rationale and the scientific one may be helpful in certain cases, but these alone cannot provide a larger philosophical framework for answering what Henket calls 'the next question', of 'which twentieth century buildings should be selected to preserve and how should we preserve them?'

Docomomo's practice is far ahead of any other organization's in this respect, but is still bounded by the fire-fighting context in which its problems are presented to it. Much pragmatic experience and theoretical debate has been summarized into a 'Diagnostic chart for assessing preservation and conservation priorities' which offers a powerful decision-making tool in relation to a particular monument. Under six headings this chart asks: Is the INNOVATION here Social, Technical or Aesthetic? Is the historical STATUS of the building Iconic or Ordinary? Is its IMPORTANCE Local, National or International? Which STRATEGY is the most appropriate: Restoration back to original, Pragmatic restoration, Economic reuse or Documentation only? What TIME-FRAME is appropriate for action: Immediate, Short-term or Long-term? And finally, what is the appropriate source of FINANCE: Private local, Public local, Private national, Public national, or International? (Henket, 1998).

These six parameters originated in the thinking of various Docomomo members and were assembled 
into a collective structure at the early Conferences. Thus the 'strategy' options derive from the contribution of International Secretary Wessel de Jonge at the First Conference in 1990 (de Jonge, 1991). The categories for evaluating 'innovation' [Fig. 4] were presented by me to the Second Conference at the Bauhaus, Dessau, in 1992 (Cooke and Richards, 1993). The bulk of professional work in the national groups has involved applying this analysis to practical tasks and somehow, by superhuman efforts, achieving them. But we still don't know why, at a cultural and societal level, we are doing it.

\section{Retrieving a philosophical basis}

At the heart of this diagnostic chart is one factor which is re-establishing itself, in an increasingly resource-conscious and cash-starved world, as a moral virtue in its own right. That is 'economic reuse': an imaginative updating to new standards of energy efficiency, sustainability and today's social needs, in a spirit that continues the progressive technical and social approach of Modernism. John Allan, the London specialist on Lubetkin's work, has been a pioneer and propagandist of this approach to the important but non-'iconic' legacy of Momo. He has described it as 'Momo's Second Chance' (1999), but history shows that it corresponds very closely to the traditional way in which a good building was confidently but respectfully updated to the needs of successive generations. Historically, however, this was generally a pragmatic rather than a morally explicit approach. Indeed if we go back 150 years to the man who first laid out the moral issues surrounding conservation, to John Ruskin in 1849 , we find the relative novelty of this principle highlighted. He observes in his Seven Lamps of Architecture, that

'The idea of ... practising present economy for the sake of those yet unborn ... never takes its place amongst the publicly recognised motives of our action. Yet this is not less our duty. God has lent us the earth for our life. It belongs as much to those who are to come after us' (Ruskin, 1849).

If Ruskin addresses the ecological aspect of our present debates only tentatively, he is vehement on the issue we call 'authenticity'. His message seems to me a vitally important one for us in today's world of increasingly 'virtual' experiences. Our use of electronic communications media serves as a constant reminder that virtuality reduces our experiences of 'real' bodily space. Its destruction of real time as measured by our biological decay is perhaps more pernicious, however, as it feeds the already over-nourished appetite for means to deny our own mortality. Far more powerfully than Walter Benjamin did later, with his concept of 'aura' (1936), Ruskin describes how the piece of genuine old fabric
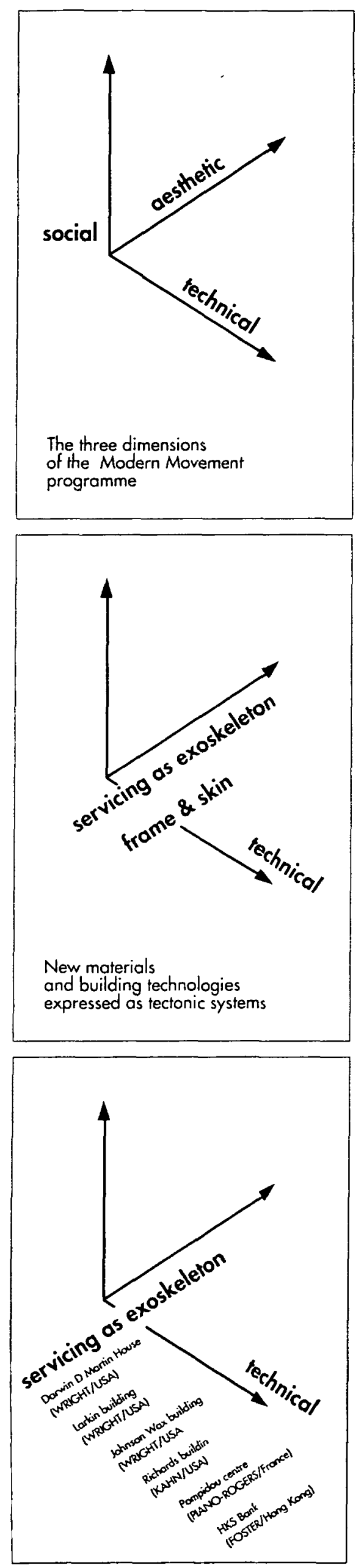

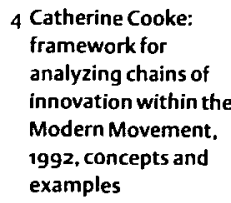

4 Catherine Cooke: analyzing chains of innovation within the 1992, concepts and

\section{${ }^{3}$}


empowers a building with what he deems to be 'its greatest glory', namely

'that deep sense of voicefulness, of stern watching, of mysterious sympathy, nay, even of approval or condemnation, which we feel in walls that have been washed by the passing waves of humanity. It is in their lasting witness against men, in their quiet contrast with the transitional character of all things, in the strength which, through the lapse of seasons and times ... connects forgotten and following ages with each other ... [It is in this] that we are to look for the real preciousness of architecture' (Ruskin, 1849).

By definition, this quality of 'witness' is not something that can be 'restored', since the new material manifestly has not 'witnessed'. To present the new as equivalent to the old is thus to perpetrate 'a lie'. Buildings should be properly maintained, but
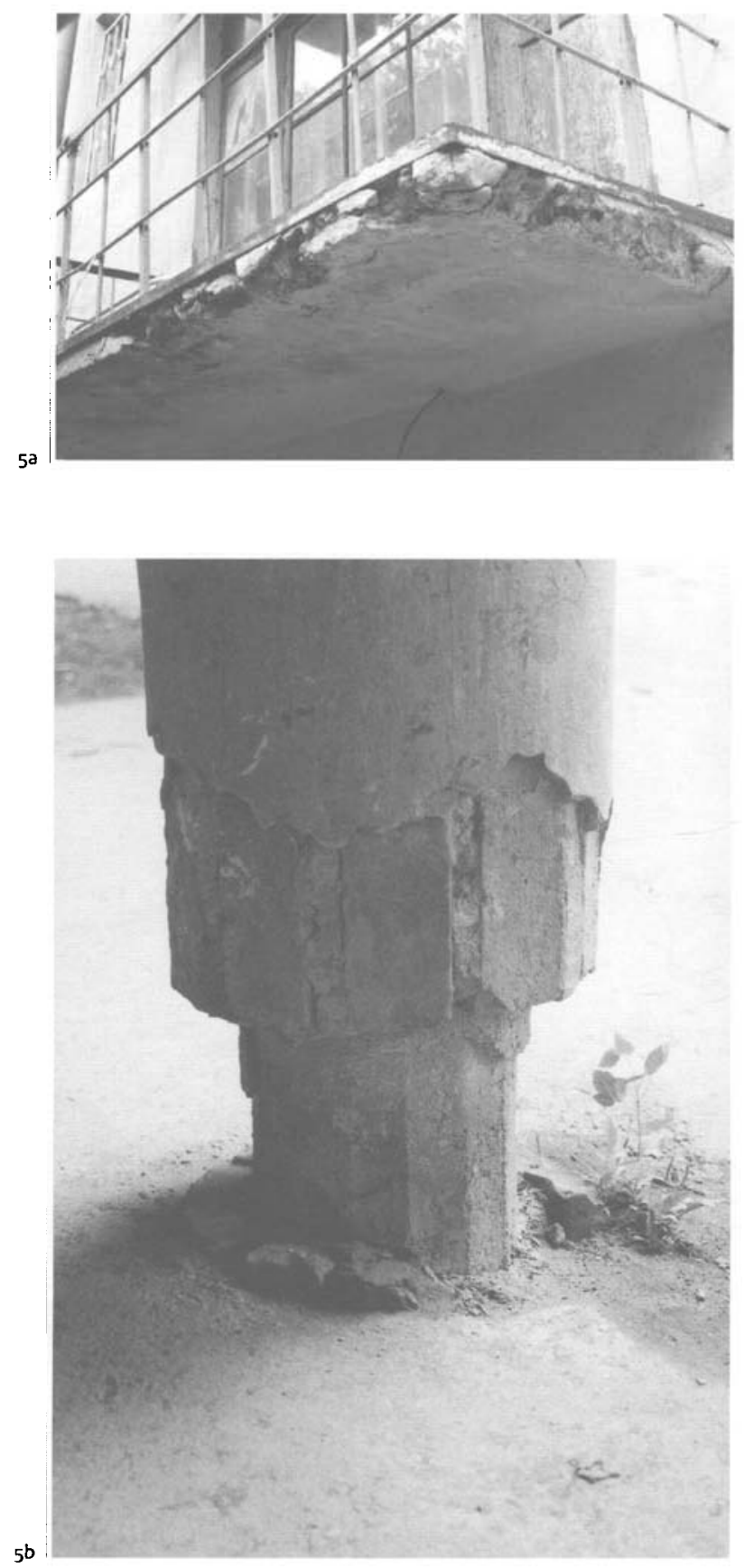

when they can no longer be patched up, moral honesty requires us, in Ruskin's view, to 'Look the necessity for destruction full in the face. Accept it as such, pull the building down'. But we should do this with self-awareness and recognize it as a rite of passage. Let the end come 'declaredly and openly and let no dishonouring and false substitute deprive it of the funeral offices of memory' (Ruskin, 1849).

Given the state of many Momo buildings [Figs. 5a and b] it is worth noting that when Ruskin and William Morris founded their Society for the Protection of Ancient Buildings from such 'restoration', 40 years later, they placed great emphasis upon the value of fragments, on 'preserving bits' [Fig. 5C]. Even bits which might in themselves be 'valueless', they insisted, can suffice to give 'the reverie of the wayfarer ... something authentic to draw upon' (Morris, 1877).

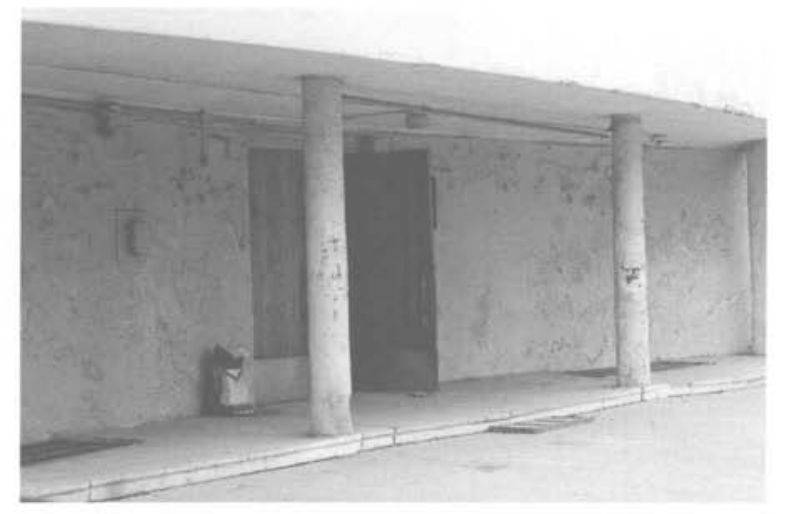


These are powerful reminders about the important mechanism which old buildings offer for the constant regrounding of our own existences in real time. Today this seems to me to be perhaps the most important kind of education-for-life that history can provide and that 'witnessing material' of a building, aged by visible real-time decay, is the uniquely potent tool in this process. In looking for 'why' we should save old buildings, this is one reason of particular relevance to our turn-of-century condition. The less obviously architectural writings of Nietzsche offer us some others.

\section{Defining a cultural purpose}

It is hard to say whose writing seems more tediously unfocused to the modern reader, Nietzsche's or Ruskin's, but both reward our efforts by occasional passages of illuminating clarity. Where Ruskin's 'Lamp of Memory' of 1849 offers us a mechanism for communicating the realities of time and mortality, Nietzsche's enormously long essay ' On the uses and disadvantages of history for life' (1874), written 25 years later, offers a very practical approach to analyzing the different cultural purposes this history can serve. As the 'most extended critique of the nineteenth-century's unprecedented sense of, and preoccupation with history' from the most iconoclastic of early-Modern philosophers (Hollingdale, 1990), its message is very appropriate to our equally history-obsessed period.

First, Nietzsche insists, historical knowledge is not automatically beneficial to us. "The question of the degree to which life requires the services of history at all is one of the supreme questions in regard to the health of a man, a people or a culture'. The challenge is one of balance. If we are to navigate between the paralysis of knowing too much history and the happy freedom of cattle with no memory at all, we need a clear conception of what history can do for us. 'Life is in need of the services of history' he concludes, but 'an excess of it is harmful'. Above all we must address the past from a position of confidence in ourselves.

'The study of history is something salutary and fruitful for the future only as the attendant of a mighty new current of life, of an evolving culture for example, that is to say only when it is dominated and directed by a higher force and does not itself dominate and direct' (Nietzsche, 1874). This 'higher force' is 'living man ... as a being who acts and strives, as a being who preserves and reveres, as a being who suffers and seeks deliverance'. These three dimensions of man's life, says Nietzsche, 'correspond to three species of history' which he calls, 'in as far as they are separable, the monumental, the antiquarian and the critical' (1874). 'Monumental' history shows:

'that the great moments in the struggle of human individuals constitute a chain, that this chain unites mankind across the millennia like a range of human mountain peaks in which the summit of some long-ago moment is still for me living, bright and great' (Nietzsche, 1874).

Only through such a 'relay-race does greatness go on living' he says. From knowledge of these peaks man 'learns that the greatness which once existed was in any event once possible and thus may be possible again'. In other words, it sets our standards. At the same time it is a dangerous territory in which false analogies can 'inspire the courageous to foolhardiness and the inspired to fanaticism'. It also perniciously suggests that the only people and achievements worth remembering are the exceptions, those 'with something strange and unnatural about them'.

'Antiquarian' history balances this by valuing the ordinary. 'It spreads a simple feeling of pleasure and contentment over the modest, rude and even wretched conditions in which a man or a nation lives.' Through this the individual may root himself through an awareness that

'Here we lived, for here we are living; and here we shall live, for we are tough and not to be ruined overnight. Thus with the aid of this "we" he looks beyond his own individual transitory existence and feels himself to be the spirit of his lineage, his race or his city' (Nietzsche, 1874).

This record of the ordinary helps us to savour our existence within a larger collective experience over time, but it too 'paralyzes' us, says Nietzsche, 'from the moment it is no longer animated and inspired by the fresh life of the present'. Society starts to think that 'the fact that something has grown old demands that it be made immortal ... Then it must seem arrogant or even wicked to replace such an antiquity with a novelty ... which is evolving and has just arrived' (Nietzsche, 1874).

This familiar situation shows 'how necessary it is to mankind to have a third mode of regarding the past: the critical'. This liberates us to move forward. 'If he is to live, man must from time to time employ the strength to break up and dissolve a part of the past.' He must have confidence 'to bring it before the tribunal, scrupulously examining it and finally condemning it' (Nietzsche, 1874).

\section{Applying this 'for life'}

Each of these 'modes of regarding the past' offers us an operational, forward-looking and above all human-centred criterion against which to judge the elements of our legacy. Unless we can externalize and order our historical knowledge in this way, says Nietzsche, it becomes 'a huge quantity of indigestible stones man drags around with him'. The result he warns against is a syndrome we surely recognize: it will 'not be real culture at all, but only a kind of knowledge of culture'. There will be 'an idea of and a feeling for culture, but no true cultural achievement emerges from them' (1874).

Looking around at today's superfluity of 'heritage' and the uncritical listing of monuments whose relevance to us we cannot prioritize, Nietzsche's voice is refreshing and empowering. So too is his warning against 'knowledge' produced by the specialist 'students of history': those 'over-ripe apples' and 'exhausted hens', 'compelled to lay eggs too quickly' - these 'eggs' being, as he puts it, 'thicker and thicker books' on 'smaller and smaller' subjects 
(1874). None of this, in his words, is 'harmonious' in its nature. We need the confidence to take a broader view of the real functions of this heritage within our own time and society. Only then can we decide which buildings best answer each of our larger needs and establish an overall strategy for our building stocks of this period. (Let other groups attend to the rest.)

The categories, as Nietzsche said, are not entirely separable. Much greater clarity of intention and freedom of action will result, however, from attempting the intellectual exercise and engaging wider circles in discussion of each building's value at this level. Precisely because all buildings reflect past values and demand present resources, their connotations, whether explicitly or not, are unavoidably philosophical and political. If we care for this Momo work, we cannot avoid that dimension of it.

Those buildings which we decide have monumental status as steps in the 'relay-race' or 'chain of peaks', which have fed greatness into the life of our community, do then demand a very special reverence and strategy. Maybe they are very few. Here we must recognize; where the achievement is aesthetic, that tolerances for alteration may indeed be as fine as with the greatest paintings, sculpture or works of poetry: Those buildings still capable of transmitting a supreme aesthetic experience should not be asked to 'pay their way' with a new function, any more than Mona Lisa does. But they can only contribute culturally if the qualities in which their greatness resided are preserved, if restoration of surfaces and replacement of components has not put their magical relationships out-of-tune.

Certainly there are some elements of the 'chain of peaks' which our past neglect has put beyond what Ruskin would have accepted as repair. We need courage to recognize these as far more useful for life in the role of testaments and 'witnesses'. That role always depends, however, on education that informs today's passer-by of the 'greatness' to which remaining fragments testify, or, in the language of Docomomo's Diagnostic Chart, of the 'innovation' which the original structure embodied.

\section{Confident use of the critical function}

Education is also the essential foundation for individual and community decisions about the 'antiquarian' heritage. A massive industry of 'local history' in the UK, like kraevedenie in Russia, currently feeds this sense of 'here we lived' to the point of indigestion, but in a manner that is very selective. In both contexts our task is surely to win the historical project of Momo its due place among the other myths of that popular narrative. The constipation of the whole listing system with us, and I suspect more widely, derives from selective over-feeding of this 'antiquarian' appetite. The situation is made worse by the tendency to apply criteria that are more appropriate to 'monumental peaks' to this very different category. As we were warned in 1874 , confident use of the 'critical' function is the condition of real cultural progress. When the material remnants of that history become 'value- free' bits of virtual entertainment, they would indeed, as voices from Ruskin through Nietzsche to those early Docomomo heretics have asserted, be better honestly gone.

As I admitted earlier, I too thought the heretics' view unhelpful to the new cause in 1990. Ten years later a different situation and a more level playing field around the Momo heritage enables me to see its merits. Pawley very honestly described how

'I visited the maison Savoye outside Paris as a student in summer 1957, when this great Corbusier villa was a ruin surrounded by waisthigh grass and nettles ... Never was the enormous authority of this machine for living in ever so well expressed as in this scene of picturesque desolation. It was like stumbling upon a forgotten battlefield, which in a sense was exactly what it was' (Pawley, 1991).

Seven years later my own experience of that place [Figs. 6a-c] was identical. (It was not yet considered a 'monument'.) The experience of an architecture that had 'fought for something' was completely unforgettable, as it is today in the presence of comparable Constructivist buildings in Russia. At one level, as Pawley admits, this notion of 'terminal neglect' as a 'radical alternative' to restoration is 'bathed in a sentimentality of its own'. Yet the power of authentic remnants to engage the emotion and the mind, to link the imagination to other lives and other times, is unmatched. Not for nothing did an earlier Romantic movement seek to replicate this effect by constructing artificial ruins of Antiquity in its private parks.

There is a line to be negotiated between Benjamin's 'works of art in an age of mechanical reproduction', which insists on the 'artisticness' of mechanically produced goods, and 'reproductions' in the sense of fakes (1936). The perfect re-creation of a small jewel like Mies van der Rohe's Barcelona Pavilion conveys some sense of the original spatiality and tactile values (and rarely is one convincing without the other). But take the reconstruction much bigger than that and we face what the other early Docomomo heretic called 'the embarrassment of the lifeless material presence of a fake corpse' (Reinink, 1990). Then we are better off with fragments or just documentation.

\section{Learning to be selective}

These arguments are old ones. What Ruskin and Nietzsche offer are criteria that go beneath the intrinsic qualities of the objects themselves to the issue of their value to us in the difficult business of living and moving on. The UK's Momo heritage comprises an over-supply of relative trivia. Ekaterinburg's heritage contains more high-quality buildings than it can hope to sustain. Without selectivity we shall all drown as they become, in the English phrase, 'mill-stones around our necks' or what Nietzsche called, 'a huge quantity of indigestible stones man drags around with him'.

This takes us into territories which are spiritual, psychological and political, but in a world of scarce resources and competing demands these are the only 

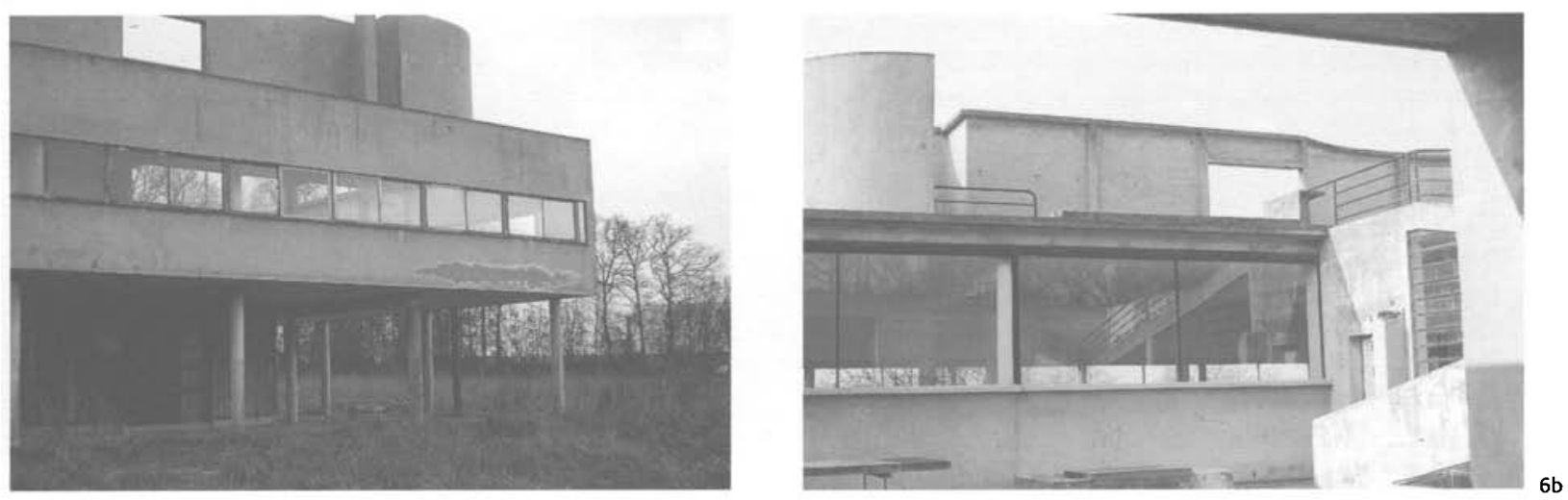

\section{Picturesque \\ desolation. The \\ powerful impact of \\ an architecture \\ which has 'fought for \\ something': Le \\ Corbusier's Villa \\ Savoye, Poissy, \\ 1929-31, in 1964 \\ a Looking towards \\ the first floor living \\ room \\ b Terrace view \\ towards temporary \\ enclosure to living \\ room \\ c Corner of terrace at \\ foot of ramp}

directions to which we can look for morally arguable criteria. Two other activities must go in parallel with this debate. The first must be education to feed the sensibilities and historical understanding of the population. The second must be the maximum use of designerly imagination. If we accept that the range of strategic options is wide open, this is the skill which can convert those options into potent human experiences. Then there can be some hope that these remains of past battles will not just foster 'a knowledge of culture' but help a new generation towards 'true cultural achievement'.

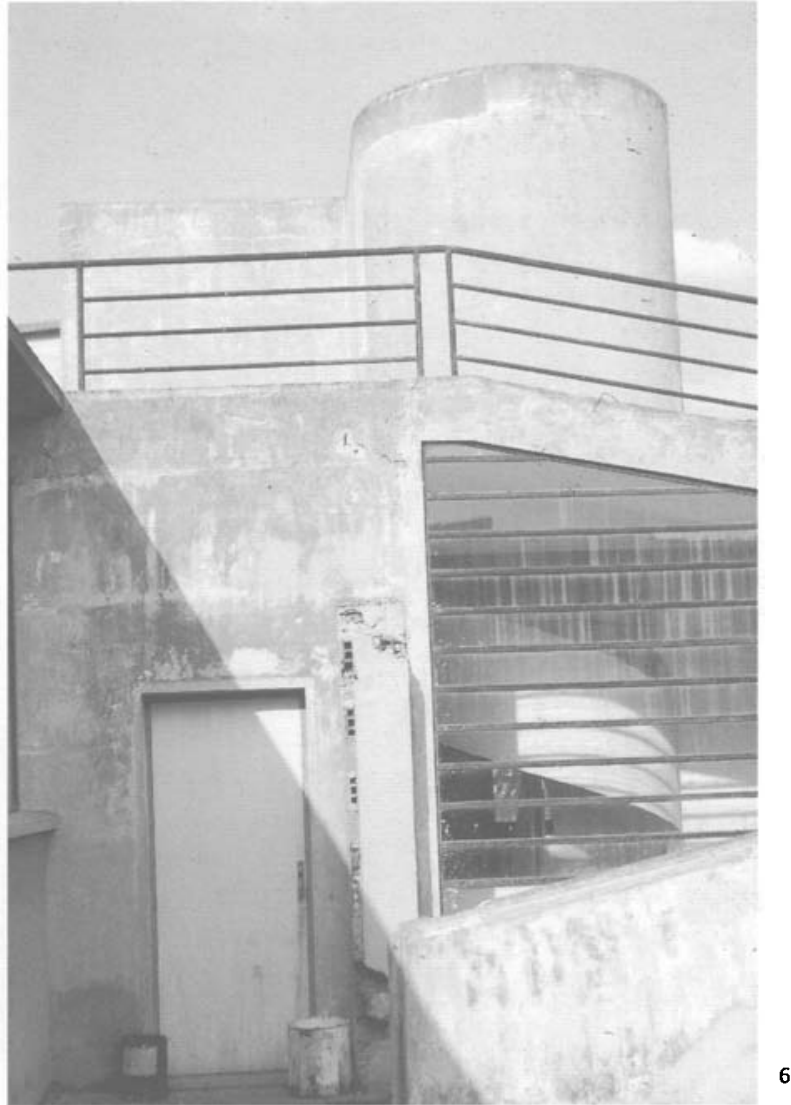

\section{Notes}

1. Docomomo is the acronym of the International Working Party for Documentation and Conservation of Buildings, Sites and Neighbourhoods of the Modern Movement. Founded in the Netherlands in 1989 it now has national groups in 38 countries. Further information can be found at: www.ooo.nl/docomomo. Docomomo-UK embraces England and Wales. Docomomo-Scotland is a separate group.

2. For the international debates, see Jukka Jokilheto, The History of Architectural Conservation. Butterworth, Oxford, 1999. Jokilheto is Assistant to the Director General of ICCROM and President of the International Training Committee of ICOMOS. On the UK history, see John Delafons, Politics and Preservation: a Policy History of the Built Heritage, 1882-1996, E \& FN Spon, London, 1997.

3. Perhaps the most influential have been David Lowenthal, The Past is a Foreign Country, Cambridge University Press, Cambridge, 1985 , and R. Samuel, Theatres of Memory, London, Verso, 1994.

4. John McAslan \& Partners, London. As this paper goes to press in arq the local council's attempts to divest itself of the 'burden' of this great building are awaiting their final outcome amid heated feelings and much controversy.

\section{References}

Allan, J. (1998). 'MOMO's second chance: the revaluation of inner urban housing in Britain', in Cunningham, A. (ed.), Modern Movement Heritage, E \& FN Spon, London. Also a shorter version in Vision and Reality: Proceedings of the Fifth International Docomomo Conference, Stockholm, 1998, Swedish Museum of Architecture, Stockholm, 1999

Benjamin, W. (1936). 'The work of art in the age of mechanical reproduction' in Benjamin, $W$. (1973), Illuminations, Fontana, London, pp. 219-253.

Cooke, C. and Richards, I. (1993). 'Modern Movement documentation as a central resource for 
$148 \mid$ arq $\cdot$ vol $4 \cdot$ no $2 \cdot 2000 \mid$ issues

architectural education', Proceedings of the Second International Docomomo Conference, Dessau, 1992, Bauhaus e.V., Dessau.

Delafons, J. (1997). Politics and Preservation, E \& FN Spon, London.

Department of the Environment and Department of National Heritage, Planning Policy Guidance 15. September 1994, reproduced as Appendix C in: Delafons, J. (1997). Henket, H-J. (1998). The icon and the ordinary' in Cunningham, A. (ed.) (1998), Modern Movement Heritage, E \& FN Spon, London.

Heynen, H. (1991). 'The issue of transitoriness in modern architecture', Proceedings of the First International Conference of Docomomo, Eindhoven, 1990, Eindhoven University of Technology, Eindhoven, republished in Cunningham, A., (ed.) (1998), Modern Movement Heritage, E \& FN Spon, London. Also Henket, H-J. (1998), 'The icon and the ordinary', in
Cunningham, A. (ed.) (1998).

Hollingdale, R.J., (tr.) in Nietzsche, F. (1990). Beyond Good and Evil, Penguin, London.

de Jonge, W. (1991) 'Contemporary requirements and the conservation of typical technology of the Modern Movement', Proceedings of the First International Conference of Docomomo, Eindhoven, 1990, Eindhoven University of Technology, Eindhoven.

Morris, W. (1877). Manifesto of the Society for Protection of Ancient Buildings, quoted in: Delafons (1997). Nietzsche, F. (1874). 'On the uses and disadvantages of history for life' in Untimely Meditations (Unzeitgemässe Betrachtungen), English edition, Cambridge University Press, Cambridge, 1997, pp. 57-123.

Pawley, M. (1991). 'A modern morituri', Proceedings of the First International Conference of Docomomo, Eindhoven, 1990, Eindhoven University of Technology,
Eindhoven.

Reinink, W. (1991). 'Controversy

between functionalism and restoration: keep Zonnestraal for eternity as a ruin', Proceedings of the First International Conference of Docomomo, Eindhoven, 1990, Eindhoven University of Technology, Eindhoven. Ruskin, J. (1849). The Seven Lamps of Architecture, Constable, London facsimile edition, 1989 .

\section{Illustration credits}

arq gratefully acknowledges:

Alan Powers, $1 \mathrm{a}$ and $\mathrm{b}$

Charlotte Benton, $2 \mathrm{~b}$

Catherine Cooke, $2 \mathrm{c}-\mathrm{e}, 3 \mathrm{a}-\mathrm{f}, 4,5 \mathrm{a}-\mathrm{c}$ and $6 a-c$

De La Warr Pavilion Trust, af

Docomomo-UK, 2 a

\section{Biography}

Catherine Cooke is a lecturer in Design at the Open University and is currently Chair of Docomomo-UK. 